Международная Объединенная Академия Наук

\title{
Научные тенденции: Филология, Культурология, Искусствоведение
}

\author{
Сборник научных трудов \\ по материалам \\ XIII международной научной конференции
}

26 августа 2018 г.

ScIENGePubLic

Санкт-Петербург 2018 
УДК 001.1

ББК 60

H34

Научный диалог: Филология, Культурология, Искусствоведение. Сборник научных трудов, по материалам XIII международной научно-практической конференции, СанктПетербург 26.04.2018 г. Изд. ЦНК МОАН, 2018. - 40 с.

\section{SPLN 001-000001-0327-FI \\ DOI 10.18411/spc-26-08-2018 \\ IDSP 000001:spc-26-08-2018}

В сборнике научных трудов собраны материалы из различных областей научных знаний. В данном издании приведены все материалы, которые были присланы на XIII международную научно-практическую конференцию Научный диалог: Филология, Культурология, Искусствоведение

Сборник предназначен для научных работников, преподавателей, аспирантов и студентов.

Все материалы, размещенные в сборнике, опубликованы в авторском варианте. Редакция не вносила коррективы в научные статьи. Ответственность за информацию, размещенную в материалах на всеобщее обозрение, несут их авторы.

Информация об опубликованных статьях будет передана в систему Российского индекса научного цитирования (РИНЦ) и наукометрическую базу SPINDEX

Электронная версия сборника доступна на сайте ЦНК МНИФ «Общественная наука». Сайт центра: conf.sciencepublicru

УДК 001.1

ББК 60 


\section{Содержание}

\section{РАЗДЕЛ І. ФИЛОЛОГИЯ}

Денисенко А.М. Особенности грамматических трансформаций при переводе англоязычных экономических текстов (на материале интернетиздания “The Economist”) ........................................................................... 4

Евстафьева М.А., Цветкова А.А. Механизмы смешного: поиски общих познавательных начал 6

Пашкова Е.А. Языковые и социокультурные особенности песенного дискурса (на материале русского и английского языков).

Родионова И.П. Проблема определения терминов «языковой контакт» и «смешение языков»....

Касьяненко В.В. Политические идеи Ивана Грозного и А. Курбского и их изучение в отечественной исторической науки 


\section{РАЗДЕЛ І. ФИЛОЛОГИЯ}

\section{Денисенко А.М. \\ Особенности грамматических трансформаций при переводе англоязычных экономических текстов (на материале интернет-издания "The Economist")}

Донской государственный технический университет (Россия, Ростов-на-Дону)

doi: $10.18411 /$ spc-26-08-2018-01

idsp: 000001:spc-26-08-2018-01

Необходимость применения грамматических трансформаций обусловлена тем, что грамматический строй английского и русского языка существенно различается.

Предложение на любом языке воспринимается в единстве его лексического содержания и грамматической формы. Грамматическая форма никогда не мыслится в отрыве от ее словесного, вещественного содержания. И все же без учета грамматического оформления невозможно понимание иноязычной фразы. Незнание специфики английских конструкций, как правило, мешает правильному пониманию смысла предложения. Грамматическая форма и синтаксическая конструкция воспринимаются при переводе как неразрывное целое с их лексическим содержанием. Если соответствующей грамматической формы нет в переводимом языке, то появляется необходимость произвести трансформацию. В данной статье представлена часть проведенного анализа применения таких грамматических трансформаций, как перестановка, замена, добавление и опущение.

Прежде чем переходить непосредственно к обзору анализа, необходимо рассмотреть классификацию грамматических трансформаций, которой мы придерживались со время исследования.

Во время данного исследования мы использовали определенную классификацию грамматических трансформаций, а именно описанную Виленом Наумовичем Комиссаровым. Грамматические трансформации он разделяет на два типа:

1. Перестановки - изменение расположения языковых элементов в тексте перевода в сравнении с текстом подлинника. Элементами, способными подвергаться перестановке, являются обычно слова, словосочетания, части сложного предложения и самостоятельные предложения в строе текста.

2. Замены - наиболее распространенный и многообразный вид переводческих трансформаций. В процессе перевода замене могут подвергаться грамматические единицы - формы слов, части речи, члены предложения, типы синтаксической связи и т.д. [1].

В ниже приведенных примерах можно наблюдать использование комплексной грамматической трансформации, которая сочетает в себе перестановку и замену.

Had this policy been adopted, the subsequent history of the treaty might well have been quite different (www.economist.com)

Если бы такая политика была принята, последующая судьба этого договора вполне могла быть совершенно другой (www.inopressa.ru);

Had it been as easy as that, no special negotiations would have been necessary (www.economist.com)

Если бы это было так просто, не понадобилось бы никаких специальных переговоров (www.inopressa.ru).

В представленных примерах трудность представляет перевод бессоюзных придаточных условных предложений с частичной или полной инверсией. 
В следующих примерар используется та же комплексная трансформация перестаровка+замена, но уже по причине того, что словосочетания типа прилагательное+существительное приобрело клишированную тенденцию перевода на русский язык типом существительое+существительное.

They underutilize and misuse valuable human resources; and they often give rise to political or social turmoil, often marked by ideological or ethnic polarization, which then leads either to wide policy swings or to policy paralysis (www.economist.com).

Они в недостаточной мере и неправильно используют иенные человеческие ресурсы, а зачастую и приводят к политическим или социальным потрясениям, часто сопровождаюшимся идеологической или этнической поляризацией, что затем приводит либо к резким политическим колебаниям, либо к параличу политики (www.inosmi.ru).

There has been some progress in identifying the factors causing economic inclusiveness to decline in the last three decades (www.economist.com).

Были достигнуты некоторые успехи в вылялении факторов, вызывающих снижение инклюзивности экономики в последние три десятилетия (www.inopressa.ru).

Как показал анализ, при переводе текстов экономической тематики личные предложения переводятся неопределённо-личными, т.е. при помощи грамматической трансформации замены членов предложения.

At last an agreement was arrived at (www.economist.com)

Наконец пришли к соглашению (www.inosmi.ru);

This article is often referred to (www.economist.com)

На эту статью часто ссылаются (www.inopressa.ru);

But we cannot assume that getting the diagnosis right will be sufficient to overcome political gridlock (www.economist.com).

Но не следует и полагать, что правильного диагноза будет достаточно для преодоления политического тупика (www.inosmi.ru).

Так же под отдельной трансформацией Н.В.Комиссаров выделяет нулевой перевод.

Нулевой перевод, т.е. отказ от передачи значения грамматической единицы вследствие его избыточности. Нулевой перевод применяется в тех случаях, когда в исходном и переводящем языках совпадает грамматическая форма, но не совпадает традиция экспликации тех или иных элементов содержания в рамках данной формы [2].

We begin by discussing case studies where protection was clearly motivated by infantindustry considerations (www.economist.com).

Начнем с обсуждения примеров, в которых защита была явно мотивирована возмещениями соображениями о зарождающейся промышленности (www.inopressa.ru).

In the rest of this section we review the empirical research on the effectiveness of infantindustry protection (www.economist.com).

В остальной части этого раздела рассмотрим эмпирическое исследование эффективности защиты новых отраслей промышленности (www.inosmi.ru).

Грамматический прием опущение, в общем смысле, является процессом игнорирования некоторых слов, которые не несут в себе важной смысловой нагрузки. Значение таких семантически избыточных слов восполняется при переводе уже комплексно.

Our second broad conclusion was that sustained growth requires a coherent, adaptable strategy that is based on shared values and goals, trust, and some degree of consensus. Of course, achieving that is easier said than done (www.economist.com).

Наш второй общий вывод заключался в том, что устойчивый рост требует продуманной, гибкой стратегии, основанной на общих ијенностях и целях, доверии и 
некоторой степени консенсуса. Конечно, об этом проще сказать, чем этого достигнуть (www.inosmi.ru).

But as the persistence of low-growth equilibria in many countries shows, it often doesn't come at all (www.economist.com).

Но, как показывает низкий уровень роста во многих странах, часто этого так и не происходит (www.inosmi.ru).

Противоположной по смыслу грамматической трансформации опущение является трансформация добавления. Как вид грамматической трансформации, добавление характеризуется при переводе использование дополнительных слов, которые не было представлены в тексте оригинала.

In this respect, developing countries' experience holds potentially important lessons for policymakers and various stakeholders in advanced economies (www.economist.com).

В этом отношении опыт развиваюшихся стран содержст потенциально важные уроки для политиков и различных заинтересованных сторон в странах $c$ развитой экономикой (www.inosmi.ru).

Bringing together people who disagree or even distrust one another is the first step toward building a foundation for collective action in the future (www.economist.com).

Свести вместе людей, которые не согласны друг с другом или даже не доверяют друг другу - это первый шаг на пути к созданию основы для коллективных действий в будущем (www.inopressa.ru).

В заключении хотелось бы резюмировать, что основными грамматическими трансформациями, которыми пользуется переводчик при переводе текстов экономической тематики, являются перестановки, заменяя и нулевой перевод.

$$
* * *
$$

1. Комиссаров В.Н., Общая теория перевода. Москва “ЧеРо”, “Юрайт”, 2000

2. Комиссаров В.Н. Теория перевода (лингвистические аспекты) [Текст] / В. Н. Комиссаров: Учебник для ин-тов и фак. иностр. яз. - М.: Высшая школа, 1990.

\section{Евстафьева М.А. ${ }^{1}$, Цветкова А.А. ${ }^{2}$ \\ Механизмы смешного: поиски общих познавательных начал \\ ${ }^{I}$ Балтийский федеральный университет им. И. Канта \\ ${ }^{2}$ Калининградский государственньй технический университет} (Россия, Ростов-на-Дону)

doi: $10.18411 / s p c-26-08-2018-02$

idsp: 000001:spc-26-08-2018-02

Феномен смешного привлекал внимание исследователей еще со времен античности, но до настоящего времени вопрос о его глубинной природе не может считаться окончательно решенным. Как представляется, причина имеющихся в этом плане неудач связана с не вполне корректными исходными теоретическими допущениями. В частности, в каждой из выдвигаемых теорий всякий предлагается, по сути, лишь одна основная предпосылка смешного. Так, еще Аристотель начала смешного сводил к особой реакции человека на непосредственно не относящиеся к нему опасность или вред. «Смешное - это какая-нибудь ошибка или уродство, - писал он - не причиняющее страданий и вреда, как, например, комическая маска. Это нечто безобразное и уродливое, но без страдания» [Аристотель 1998:1070].

Сходных взглядов на начала смешного придерживался М.М. Бахтин, который также полагал, что «отрицательное и положительное в явлениях комического неразъединимо слиты, между ними нельзя провести четкой границы» [Бахтин 1997:50], и видел в комическом недолжное, а в смехе - своеобразный способ его исправления. 
Чуть менее жесткую позицию во взглядах на глубинную природу смешного занимал В.Я. Пропп, полагавший что смешное возникает во взаимодействии двух начал. С одной стороны, это наличие у человека некоторых представлений о должном, моральном, правильном, часто имеющих бессознательный характер и становящихся своеобразным «инстинктом должного». С другой стороны, это сделанное человеком наблюдение, что в окружающем мире есть нечто противоречащее этому инстинкту. «Короче говоря, - заключил В.Я. Пропп, - смех вызван наблюдением некоторых недостатков в мире человеческого обихода. Противоречие между этими двумя началами есть основное условие, основная почва для возникновения комизма и вызываемого им смеха» [Пропп 1997: 224-225].

Тем не менее установка на поиск основного и универсального начала смешного была поддержана некоторыми современными исследователями как неизбежная и безусловно верная. В частности, ее специально отметил Л.В. Карасев, с одной стороны, провозгласив единство смеха в разных условиях, а с другой - еще раз утвердив аристотелевскую концепцию смешного. Ср.: «В написанном о смехе все время повторяются две важнейшие идеи, которые вряд ли смогут быть поколеблены в обозримом будущем. Первое - сущность смеха, несмотря на все кажущееся бесконечным многообразие его проявлений, едина, и второе - сущность эта состоит в усмотрении, обнаружении смеющимся в том, над чем он смеется, некоторой “меры зла"» [Карасев 1996: 14].

При всем этом осуществилось расширение категориальной базы исследования проблемы смешного, обусловленное стремлением увидеть ее с новых теоретических позиций языкознания. Введение в этой связи таких категорий, как пресуппозищии, импликатуры, речевые акты, возможные миры, инференции, концепты, разговорные стратегии, актуальных для прагматики, дискурсивного анализа и когнитивной семантики, расширило возможности раскрытия глубинных познавательных начал смешного. Семантика и прагматика определились как наиболее перспективные области в плане выявления исследования юмора области лингвистики. Кроме того, в основе смешного стали видеть действие нескольких разноплановых начал в разных смеховых условиях. На этой основе сложились достаточно разные, но дополняющие друг друга теории юмора.

1.Теория двухэтапного когнитивного раскрытия шутки (Д. Салс, Д. Форабоско). Эта теория сложилась в противовес концепции, согласно которой необходимым и достаточным условием возникновения у человека смеховой реакции является наличие познавательного противоречия как такового [cp. Nerhardt 1977; Rothbart, Pien 1977; Katz 1993]. Как отметил Д. Салс, это противоречие само по себе оказывается недостаточным - в ряде ситуаций (особенно в условиях реализации вербального юмора) необходимым является этап разрешения этого противоречия [см. Suls 1983: 41].

В частности, эту теорию разрабатывал Д. Салс, полагавший, что смешное складывается в единстве двух познавательных этапов. На первом субъект обнаруживает, что его ожидания в отношении содержания текста не подтверждаются его концовкой. По мнению Д. Салса, смешное возникает, когда субъект сталкивается с таким противоречием и испытывает потребность разрешить его либо путем обращения к информации, содержащейся в самом данном тексте, либо путем обращения к имеющемуся у него собственному информационному багажу [см. Suls 1983: 41-42]. На втором этапе человек осуществляет поиск когнитивного правила, на основе которого это противоречие в тексте получает разрешение. Такой шаг, имеющий ранг правила, выводит субъекта к новой логической пропозиции или факту опыта. Важно при этом, что отмеченный процесс не ведет к устранению данного противоречия - оно, напротив, принципиально «обретает смысл». Как определил эту ситуацию Д. Форабоско, в конце 
восприятия шутки субъект приходит к «гармонирующему противоречию» [Forabosco 1992:59].

Поддерживая точку зрения Д. Салса и других исследователей, развивающих теорию двухэтапного когнитивного постижения смешного, Д. Форабоско определил заложенное в шутке противоречие как дивергенцию от когнитивной модели референции (divergence from a cognitive model of reference), а этап разрешения этого противоречия, требующий от субъекта определенных когнитивных усилий и способностей, - как его когнитивное мастерство (cognitive mastery) [см.: Forabosco 1992: 45].

Важную роль в этой теории играют еще две категории. Первая «неконгруэнтность», которая объясняется следующим образом: «Стимул некогруэнтен, когда он отличается от когнитивной модели референции» [Forabosco 1992: 54]. Необходимо иметь в виду при этом, что такая «неконгруэнтность» не составляет характерную черту стимула как такового - она обнаруживает себя как результат отношений стимул-субъект.

Вторая категория «когнитивная модель референции», которая базируется на том представлении, что каждый субъект в своей когнитивной истории (то есть в своей истории конструирования и организации знаний о мире и познавательных методов) создает модели (или cembl, cxeмbl и т.д.). Эти модели, собственно, и составляют результат познавательного опыта человека, получаемого на основе механизмов отбора, обобщения, категоризации и так далее. Отклонение от той или иной модели возникает при «одновременном присутствии противостоящих и несовместимых аспектов, диспропорции, дисгармонии и т.д. Однако чтобы установить, что является противостоящим и несовместимым и когда дисгармония или диспропорция таковы, что воспринимаются как неконгруэнтные, необходимо провести сравнение с моделью референции [см.: Forabosco 1992: 54-56]. Ср.:

- Посоветуйте, что мне взять на обед? - обращается посетитель к официанту.

- Как вам сказать? Меньше всего сегодня жалуются на бифштекс.

В этом тексте когнитивную модель референции составляет знание о типичных отношениях посетителя и официанта в ресторане или кафе. Посетитель может запросить у официанта информацию о наиболее удачном блюде в этот день, а официант обычно дает такую информацию. Этой модели отвечает первая половина текста. Содержание же последней фразы неконгруэнтно его началу. Официант отвечает на коммуникативный запрос посетителя, но в этом ответе содержится информация не о наиболее удачном блюде, а о наименее неудачном. Складывается новая пропозиция, согласно которой ресторан или кафе, куда посетитель пришел пообедать, охарактеризуется как крайне плохой, а его кулинарное достоинство определяется не большим количеством положительных отзывов, а малым количеством нареканий. Раскрытие этого противоречия между должным и сущим, нормальным и отклоняющимся от нормы в данном тексте и составляет его смеховую основу.

2. Семантическая теория юмора, основанная на скриптах (В. Раскин). Ключевой характер в рамках этой теории имеет категория «скрипт». Как когнитивная структура он представляет собой формализованный и структурированный объем связанной семантической информации, усвоенной говорящим в процессе познания мира. Очевидно, что такой объем информации несет в себе и прагматические характеристики, обусловленные жизненным опытом человека. Так, со словом врач в русской лингвокультурной традиции связывается представление о взрослом человеке, который провел значительную часть времени, обучаясь в медицинском институте, профессионально занят тем, что принимает пациентов в кабинете, диагностируя болезни и выписывая лекарства от них; слово автомобиль порождает мысль о четырехколесном транспортном моторном средстве, управляемом человеком и 
используемом для перевозки пассажиров или грузов; слово пистолет - о ручном короткоствольном оружии, предназначенном для стрельбы.

Опираясь на эту категорию, В. Раскин исследовал познавательную природу смеховых текстов, что позволило ему сформулировать основанную на скриптах семантическую теорию юмора (the script-based semantic theory of humor) [Raskin 1985: 99-147]. Эта теория базируется на следующих основных положениях, которые, по мнению автора, составляют необходимые и достаточные условия для того, чтобы текст был смешным. А именно, «текст можно охарактеризовать как содержащий шутку, если соблюдены два следующих условия:

1) он должен быть совместим полностью или частично с двумя различными скриптами;

2) два скрипта, с которыми текст совместим, должны быть в особом смысле слова противоположны» [Raskin 1985: 99].

Как отметил В. Раскин, противопоставляемые подобным образом скрипты могут быть сведены к ряду относительно стандартных ситуативных оппозиций:

- реальная /нереальная ситуация (в самом общем плане);

- актуальная/неактуальная ситуация;

— возможная/невозможная ситуация;

- нормальная/ненормальная ситуация (в более или менее конкретном плане);

— плохая/хорошая ситуация;

- не секс/секс;

- деньги/не деньги,

— жизнь/смерть и др. [см.: Raskin 1985:111; Attardo and Raskin 1991:308].

Так, автор приводит следующий пример, совместимый с двумя различными скриптами, которые условно можно обозначить как «больной» и «любовник», а оппозицию между ними обозначить как «актуальная /неактуальная» (вариант «не секс/секс»).

«Доктор дома?» - спросил больной бронхиальным шепотом.

«Нет, - прошептала в ответ молодая симпатичная жена врача. - Заходите».

Первое предложение своими лексическими компонентами доктор, больной, бронхиальный шепот задает скрипт «больной», представляющий посещение врача человеком (мужчиной) в условиях остро проявляющегося у него заболевания бронхов. До тех пор, пока воспринимающий субъект не познакомится с вторым предложением этого текста, для него будут неактуальными характеризующие особенности первого предложения (в данном случае «не секс/секс»).

Актуальные для этого предложения инференции таковы:

— больной - мужчина;

— доктор - медик высокой квалификации, специализирующийся на лечении бронхов;

- доктор принимает больных у себя дома;

- неизвестно, доктор дома или нет.

В целом первый скрипт можно представить метаописательно следующим образом: «Некий мужчина, страдающий заболеванием бронхов, хочет знать, присутствует ли в своем жилище специалист с высшим медицинским образованием, врач, способный помочь ему в излечении заболевания».

Второе предложение включает в себя такие компоненты: больной обращается $\kappa$ жене врача, жена врача молода и симпатична, она приглашает больного в дом, делает это шепотом, в определенной мере определяющие содержание другого скрипта. Однако для него более значимы дополнительные и более широкие инферентные содержания: 
— жена врача осознает свою привлекательность;

- она предполагает, что производит впечатление на пришедшего мужчину;

- шепот больного она расценивает как проявление интимных установок;

- ее шепот - ответное проявление интимных установок;

- она приглашает пришедшего мужчину потому, что мужа нет дома;

- она приглашает мужчину для интимных связей.

Общее содержание этого скрипта определяется так: «Жена врача, молодая, симпатичная и осознающая свою привлекательность, полагает, что производит впечатление на пришедшего мужчину, его шепот расценивает как проявление его интимных намерений и отвечает тем же, приглашая его в дом».

Таким образом, содержание второго предложения имплицирует новый скрипт, который условно может быть назван «любовник», причем содержательная структура первого предложения этому не противоречит [cм. Raskin 1985:117-127].

В этих условиях важную роль играет «семантический триггер»- содержание, переключающе первый скрипт на второй. Автор данной теории определяет два вида таких триггеров: действующие в условиях двусмысленности (ambiguity) и действующие в условиях содержательной несовместимости (contradiction). Триггеры, актуальные для условий двусмысленности, обычно действуют в текстах, построенных на явлениях полисемии или омонимии. В данном случае действует триггер, актуальный для текстов несовместимости. На формальном уровне это слова «Нет... Заходите» и в дополнение к ним - обстоятельство «шепотом».

3. Общая теория вербального юмора (В. Раскин, С. Аттардо). Семантическая теория юмора, основанная на скриптах, получила дальнейшее развитие в общей теории вербального юмора (General Theory of Verbal Humor), разработанной совместно С. Аттардо и В. Раскиным [Attardo and Raskin 1991: 293-347]. Что именно происходит, когда мы принимаем решение рассказать шутку? С чего мы начинаем? Что происходит потом? На эти и другие вопросы авторы попытались дать ответы авторы этой теории

Следуя в этом направлении, они проанализировали ряд перефразов и вариантов одной и той же шутки и выделили шесть параметров их отличия. Эти параметры были связаны, с одной стороны, с познавательными способностями человека (knowledge resources, KRs), а с другой - с базами данных, которые характеризуют любую шутку. Эти параметры, в частности, таковы: скрипт-оппозиции, логические механизмы, ситуации, цель, нарративные стратегии и язык [см.: Attardo and Raskin 1991:297-309].

В этой теории особую роль играет категория «нарративная стратегия». Под ней понимается способ создания шуточного эффекта, закрепленный в жанре или даже микрожанре соответствующего смехового текста. Таковыми жанрами могут быть, например, загадки и данные тут же ответы на них, анекдоты в форме повествования или диалога, шутки, имеющие вид рекламного объявления, однострочные реплики и т.д. Необходимая характеристика таких текстов - некая недосказанность, причем рассказчику необходимо выстраивать смеховой текст так, чтобы воспринимающий субъект мог восстановить имеющиеся в виду смыслы.

В семантической теории юмора, основанной на скриптах, В.Раскин определил категорию «триггеры», которые выполняют в смеховом тексте функцию переключения с одного скрипта на другой. Однако он признал, что существуют и такие смеховые тексты, в которых такие триггеры отсутствуют. В результате дальнейшего изучения способов перехода от одного скрипта к другому он пришел к выводу о то, что общий фактор подобных переходов составляют логические механизмы (в частности, это может быть переход фигуры в фон или обратный ход).

Так, ошибочная логика может обеспечивать шутку, если она присутствует в чистом виде, в комбинации с другими механизмами или связана с включением в текст паралогических элементов. Например, нарушением логики обеспечивается смеховой 
эффект в следующем анекдоте. Одной из блондинок прогноз «дождь после обеда» понимается не с точки зрения общего темпорального ориентира события, а в аспекте нарушенных причинно-следственных связей: нет обеда-нет и дождя.

Две блондинки. Одна - другой:

— Ты не слышала прогноз погоды на сегодня?

- Кажется, после обеда обещают дождь.

— Ой, а я не взяла зонтик.

- Так не обедай.

Некоторые несложные юмористические тексты такого рода могут строиться по принципу хиазма - обращенного параллелизма с расположением аналогичных частей в последовательности АВ-B'A'. Этот логический механизм можно обнаружить, например, в следующей шутке:

Быть честным не значит говорить все то, что ты думаешь. Это значит - думать все то, что ты говоришь.

Еще один логический механизм такого рода - создание контекстов, включающих ложную аналогию. В лингвистике этот феномен известен как «модель заблуждения» (“garden path”). Пример шутки, в которой этот механизм активно работает, таков:

Правой или левой рукой следует помешивать кофе? - Ни той, ни другой. Следует пользоваться ложечкой.

В этом тексте сначала приводится альтернативный вопрос, в котором варианты ответа касаются части тела, осуществляющей действие. Но затем оба варианта отрицаются, а ответ (и соответственно сам вопрос) переводится в плоскость орудия. Этот логический переход в тексте шутки и составляет основу ее смехового начала.

Однако едва ли не самый главный логический механизм смешного в разработанной В. Раскиным и С. Аттардо общей теории вербального юмора - переход от одой ситуации к другой, связанный с их сопоставлением (juxtaposition). Языковое оформление этого процесса составляют многозначность или омонимия в сфере лексики. Ср.:

Две пиявки. Одна другой:

— Я тебя не отрываю?

Для этого примера актуальна многозначность глагола отрывать. С одной стороны, с ним может связываться значение 'с усилием, преодолевая сопротивление, отнять, отстранить от кого-, чего-л.’; с другой стороны, у него определяется значение 'помешать делать что-л., отвлечь от чего-л.' [MАС, т. II, с. 697]. Наличие в этом примере слова пиявка, называющего пресноводного червя, питающегося кровью животных, к телу которых он присасывается, предполагает воссоздание двух близких, но имеющих разные содержательные акценты ситуаций. Они таковы:

- одна пиявка, присосавшись к кому-то, пьет кровь этого существа, а другая пытается с усилием отделить, оторвать ее от этого источника пищи»;

- одна пиявка, присосавшись к кому-то, пьет кровь этого существа, а другая считает это занятие важным делом и интересуется, не отвлекает ли от него первую пиявку.

Эти ситуации находятся в динамично взаимодействии, постоянно переходя друг в друга.

В целом в общей теории вербального юмора определяются следующие логические механизмы: обращение фигуры и фона, хиазм, ошибочная логика, ложная аналогия и сопоставление. При этом, по мнению авторов этой теории, выделенные механизмы достаточно четко соотносятся с различными компонентами шутки, инициирующими ее продуцирование. И хотя определяющуюся иерархию этих 
способов С. Аттардо и В. Раскин считают наиболее простой и удобной для построения модели репрезентации шутки, они не отрицают возможности дальнейшей дискуссии вокруг предложенной ими иерархии на теоретическом или эмпирическом уровне [см.: Attardo and Raskin 1991:328].

4. Теория обманутого ожидания (С. Аттардо, Р. Джиора, Д. Баттлер). Стремясь определить роль и место общей теории вербального юмора в рамках когнитивных теорий, С. Аттардо пришел к выводу о приоритетности семантики в реализации этого явления. Следуя в этом направлении далее, он обратил внимание на то, что семантическое понятие «скрипт-оппозиция» оказывается тесно связанным с познавательной установкой нарушения ожиданий. В психологической теории юмора эта установка определяется как неконгруэнтность, что делает соответствующие понятия практически идентичными [см.: Attardo 1997:402-403].

Опираясь на эти положения, С. Аттардо построил трехступенчатую модель восприятия смехового текста, которая, кроме элементов противоречия и разрешения, включает в себя в качестве первой ступени фазу установки (setup). В самом деле, чтобы определить противоречие и затем разрешить его, нужно сначала иметь в наличии описание нормы [см.: Attardo 1997:411]. В большинстве юмористических текстов это описание задается их начальной частью - относительно короткой и обычно включающей несколько предложений.

Сходные теоретические положения разрабатывала Данута Баттлер, полагавшая, что комический вербальный текст является с точки зрения семантической структуры двучленным, а представляемое им комическое начало обеспечивается резким переходом просто от исходной семантической позиции к контрастирующему с ней выводу [Buttler 1968: 36].

Репрезентация исходной нормы в рамках теории обманутого ожидания имеет и несколько внутренних особенностей. Прежде всего, она задает собой закон познавательной инерции - формирует исходное положение дел, которое, собственно, оценивается далее как нормальное. Относительно этого положения дел и формируется противоречие в конечной части текста. Кроме того, исходное положение дел обладает высокой степенью прагматической доступности и базируется на нейтральном контексте, в то время как часть текста, представляющая противоречие, менее доступна для понимания и в большей мере зависит от стилевых особенностей текста. Далее, начальная часть текста, представляющая норму, является менее информативной по отношению к его завершающей части, представляющей противоречие. Этот порядок обязателен и составляет внешнее выражение закона содержательной необратимости юмористического вербального текста. Наконец, исходная малоинформативная норма разрушается завершающей частью текста, причем это происходит не постепенно, а напротив, принципиально неожиданно. Это положение специально отметила Р. Джиора, подчеркнув, что переход от первого, понимания текста ко второму, ломающему сложившееся ожидание дальнейшей нормы, должен быть по возможности более неожиданным. В случае же снижения этой неожиданности - оно может быть связано с проникновением содержаний конечной части текста, показывающих направления его альтернативного понимания, в область исходных содержаний нормы - текст больше не воспринимается как смешной [см.: Giora 1988:547-565].

Рассмотрение с категориальных позиций теории обманутого ожидания следующего юмористического текста раскрывают его семантическую природу.

Поезд дальнего следования. В каждое купе с вежливой улыбкой заглядывает проводница:

- Иностранцы есть?

Везде отвечают, что нет. Она выходит в коридор и громко кричит:

- Танька! Вырубай кондиционер! Тут одни наши! 
Начальная и наиболее значительная часть этого текста представляет как норму описываемую ситуацию - вежливость и доброжелательность проводницы российского поезда дальнего следования. На первый взгляд нейтральная деталь текста - отсутствие в вагоне иностранцев. Последняя же строка ломает эту ситуативную установку. Обнаруживается, что вежливость проводницы - фальшь, а проявляемая доброжелательность и задаваемый вопрос вскрывают ее преклонение перед иностранцами и презрительное отношение к соотечественникам. А первоначально нейтральный вопрос оказывается триггером, запускающим процесс ломки исходных семантических ожиданий.

5. Теория ситуативных скачков (М.А. Евстафьева). Осмысление теории обманутого ожидания (в двучленном варианте Дануты Баттлер) в направлении образного моделирования действительности человеком позволило продвинуться далее и взглянуть на природу вербального юмора с новых позиций когнитивной теории ситуативных скачков [см. Евстафьева 2006]. Эту теорию отличает несколько важных черт. Прежде всего, в ней отмечается, что юмористический вербальный текст всегда двухчастен, представляет две ситуации. При этом первая ситуация (интродукция, зачин) описывается детально, задается более развернуто по сравнению со второй. В ней представляется некое положение дел, воспринимаемое слушателем как первоначальная содержательная данность. Вторая же ситуация (развязка), обычно вводимая внезапно и описываемая более лаконично, радикально меняет взгляд слушателя на исходно представляемое положение дел. И чем более далекими друг от друга являются эти две ситуативные позиции, чем значительнее когнитивный скачок от первой ситуации ко второй, тем выразительнее юмористический эффект данного вербального текста.

Иными словами, в этой теории понимание глубинной природы вербального юмора из психологической сферы переводится в сферу собственно познавательную. В результате ее объяснительная сила выходит за рамки исключительно вербальных текстов и распространяется на область визуальных юмористических форм.

В связи с этим в рамках этой теории вербальные юмористические тексты могут рассматриваться с разной степенью объяснительной глубины. С одной стороны, определяются тексты, в структурном отношении более поверхностные. Их устройство отвечает распределению дискурса во времени и в ситуативном плане характеризуется как «последовательность». Схематически такие тексты представляются формулой $\mathbf{A} \rightarrow$ $\mathbf{B}$, где $\mathbf{A}$ - исходная ситуация, $\mathbf{B}-$ вторая ситуация, а символ $\rightarrow$ указывает на переход в сознании слушателя от ситуации А к ситуации В [Евстафьева 2006: 75]. Ср.:

Один мужик собрался на рыбалку. Встал рано утром, пока жена спала, потихоньку собрал удочки, банку с червями достал из холодильника, пару бутербродов намазал, чай в термосе... Вышел на улицу, а там холодина, ветер, дождик моросит. Мужик думает: «А ну ее, эту рыбалку. Не поеду!» И вернулся домой. Опять же потихоньку разделся и юркнул к жене под одеяло. Она его обнимает и сквозь сон, не открывая глаз, говорит:

- Это ты, дорогой? Замерз совсем. Ну иди скорее, согрею. А мой-то дурак на рыбалку поперся.

Первая ситуация, представленная в этом тексте, содержательно не ограничивается собственно сборами человека на рыбалку, обстоятельствами плохой погоды и его возвращением домой. В самом общем плане она демонстрирует вполне нормальную жизнь супругов, в которой муж проявляет деликатность к жене (старается ее излишне не беспокоить). Вторая ситуация - она представляется словами жены диаметрально противоположна первой по своей содержательной сути. У жены есть любовник, который приходит к ней домой, она относится к мужу с презрением. Но самое главное - об этом муж узнает от самой жены.

В этих обстоятельствах демонстрирует свою принципиальную значимость еще одна черта рассматриваемой теории ситуативного скачка. В юмористических текстах 
структурного вида $\mathrm{A} \rightarrow \mathrm{B}$ особо важную роль играет принцип обращения к имплицитно заданным смыслам. Именно они в значительной мере определяют содержательную специфику и первой описываемой в тексте ситуации, и второй, от которой зависит смеховой эффект текста. Так, в приведенном выше примере выводными являются знания о добром отношении мужа к жене, а смеховой эффект определяется неожиданностью открытия новой ситуации, обнаруживающей супружескую неверность жены и собственно принятие ею мужа за любовника.

Особую разновидность юмористических текстов структурного типа $\mathbf{A} \rightarrow \mathbf{B}$ составляют единства «вопрос - ответ». В этих условиях вопрос представляет ситуацию, которая нуждается либо в логическом утверждении/отрицании, либо в объяснении. Ср.:

- Помогает ли корень жень-шень при половой слабости?

- Помогает, если хорошо привязать.

С другой стороны, в рамках теории ситуативного скачка определяются тексты, в которых нарушается принцип темпоральной линейности и описываемые ситуации представляются в одновременности и при этом в особой игровой равнозначности. Схематически тексты такого рода представляются формулой $\mathbf{A} \boldsymbol{\&} \mathbf{B}$, где $\mathbf{A}-$ некая исходная ситуация, В - вторая ситуация, а символ \& показывает равнозначность представляемых ситуативных альтернатив [Евстафьева 2006: 76]. Ср.:

- Доктор, я постоянно кашляю...

- А травки пробовали?

- Пробовала. Хихикаю, но все равно кашляю...

В приведенном примере игровая двойственность представляемых ситуаций задается многозначностью слова трава, травки 'растительные лекарственные средства' (ср.: На траве сидеть, траву пить 'лечиться'; травник 'набор трав и кореньев, для настоек водочных и лекарственных’; Он на траве сидит, пьет травник от ломоты [Даль]) и травка (разг.) 'наркотик растительного происхождения' (Парень курит травку) [Ожегов]). Исходя из этого первая из определяющихся ситуаций (позиция доктора) - женщина употребляет лекарственные травы, а вторая (позиция пациентки) - она употребляет наркотики растительного происхождения (на это указывает характерная психологическая реакция).

По мнению некоторых исследователей, в условиях такого перехода от одной представляемой ситуации к другой важную роль играет особый триггер (или дизъюнктор (disjunktor), как вслед за А.Ж. Греймасом определяет его С. Аттардо [Attardo et al. 1994]). Они считают таковым слово или словосочетание, которые «переключают» слушателя с одной ситуации на другую и делают возможной двойственную интерпретацию текса.

Однако имеющийся материал показывает, что такой триггер в юмористических текстах имеется далеко не всегда. В целом ряде случаев переход от одной ситуации к другой осуществляется слушателем без подталкивающих к этому текстовых факторов. Так, в первом из приведенных ниже примеров ситуативная двойственность обусловлена многозначностью конструкции не доходят. Первая ситуация (она представляет точку зрения абонента) связана с идеей достижения послания при его пересылке (ср.: дойти 'прибыть в место назначения (о письмах, посылках и т. п.)'. Вторая ситуация связывается с идеей понимания (дойти (разг.) 'стать ясным, понятным, затронуть чувство, мысль' (МАC I, с. 418). «Переключение» с одной ситуации на другую обеспечивают слово и словосочетание сосредоточьтесь $u$ внимательно прочтите, но по сути - вся последняя фраза в целом, представляющая вторую ситуацию. Ср.:

Звонок оператору сотовой связи

- Девушка, до меня не доходят SMS сообщения!

— Сосредоточьтесь и внимательно прочтите их еще раз. 
Еще более показательны в этом отношении следующие примеры. В каждом из них отсутствует подобный триггер, а вторые ситуации вводится без каких-либо формальных «переключателей» и в целом. Так, в первом тексте неожиданность перехода от одной ситуации к другой обеспечивается не формальным триггером, а возможными коммуникативными условиями - привязанностью или непривязанностью вопроса Кем бы ты хотел быть? к контексту коммуникации. Во втором тексте переход от одной ситуации к другой имеет игровой характер и обеспечивается лексической омонимией, а также возможность разного понимания свободных и связанных словосочетаний, но триггер как таковой здесь отсутствует. Ср.:

Из жизни сотрудников банка. Звонок в кредитный департамент (звонит женщина):

- Здравствуйте, у меня задержка три месяца. Можно обойтись малой кровью или уже поздно?

И еще одна черта рассматриваемой теории ситуативных скачков - утверждение в юмористических текстах (и в проявлениях юмора вообще) принципиальной роли имплицитных содержаний и особой значимости актов семантического вывода. Юмористический эффект рождается не просто в скачке от одной ситуации к другой, но при условии, что вторая ситуация выводится из имеющегося контекста. Более того, именно тексты, в которых вторая ситуация имеет выводной характер, часто оказываются с точки зрения юмористического эффекта более яркими и выразительными. Человек смеется над тем, о чем он догадывается, причем именно эта догадка апеллирует к истине, отвечает реальному положению дел. Ср.:

- Спать иди, скотина! - раздался из кухни голос матери.

Сын свернул окно порносайта, муж отправил переписку с любовницей в корзину, дочь выронила палку для селфи в ванной, и только Тузик продолжал мусолить косточку под кухонным столом.

C тех пор, как я выучил азбуку Морзе, не могу уснуть под дождь. Например, вчера я услышал, что дождь позвал меня выпить. Причем трижды по имени...

В первом примере ситуация семейного переполоха, представленного в отношении разных членов семьи, внешне определена. Однако этот переполох имеет и скрытые основания - каждый из членов семьи занимается чем-то таким, что может осуждаться матерью. Вследствие этого каждый относит к себе сниженное, отчетливо грубое наименование «скотина». При этом можно догадаться, что данное наименование относится к Тузику, хотя он совершает абсолютно невинное действие.

Содержание текста во втором примере имплицирует важные дополнительные смыслы, составляющие основу смешного, - «говорящий, по-видимому, алкоголик», «желание выпить превратилось у него в навязчивую идею», «стук дождя воспринимается его больной психикой как желательные для него призывы на азбуке Морзе», «стук дождя снимает с него ответственность за пьянство».

Смех над пониманием истинного положения дел может быть спровоцирован и текстами иного рода. В них исходная ситуация представляется подчеркнуто нереальной, такой, как никогда не бывает в жизни. Лицо, воспринимающее эти тексты, осознает эту их нереальность, внутренне «исправляет», и этот переход от неистинного, логически инверсированного положения дел к истинному вызывает смех. Ср.:

Идеальная жена и идеальный муж.

- Милый, иди водку пить!

- Милая, я еще полы не домыл!

Состоятельность рассматриваемой теории ситуативного скачка и актуальность принципа семантического вывода в ее рамках подкрепляется текстами, имеющими особую структурную организацию - подчеркнутую краткость. Таковы, в частности, некоторые одностишия В. Вишневского, в которых юмористическое начало 
практически полностью обусловлено выводимыми содержаниями, вступающими в игровые отношения с непосредственно данными. Ср.:

Желанная моя, скорей бы утро!

Любимая, да ты и собеседник?!

Ну что ж, придется вами насладиться...

Мы тоже не всего читали Шнитке!

В первом примере предложение Скорей бы утро! входит в содержательное противоречие с обращением Желанная моя и позволяет сделать вывод о том, что на самом деле для лирического героя женщина, к которой он обращается, нелюбима и не желанна. Во втором примере предложение Да ты и собеседник! с дополнительной семантикой экспрессивности показывает отношение лирического героя к упоминаемой женщине исключительно как объекту плотской любви. В третьем примере слова придется и насладиться находятся в семантическом рассогласовании, что выражает скрытую мысль о реальном нежелании лирического героя вступать в отношения с лицом (он делает это по необходимости) и о сомнительности предстоящего «наслаждения». В четвертом примере сочетание читали Шнитке неадекватно с точки зрения внеязыковой действительности. Альфред Шнитке (24.11.1934 - 03.08.1998) композитор, и его музыку можно лишь слушать, и отмеченная неадекватность позволяет сделать вывод о реальной некультурности лирического героя, которую он к тому же пытается скрыть за обезличивающим мы и конъюнктивом тоже.

Итак, какая же теория в ряду рассмотренных в наибольшей степени раскрывает природу вербального юмора? Которая из них способна выйти за рамки языковых концептуальных систем и объяснить механизмы смешного, актуальные также и для образов? Существуют ли теории, применимые ко в е м видам смешного, в том числе и к черному юмору?

По мнению В.3. Санникова, полностью универсальных и всеобъемлющих теорий смешного нет, а по сути, и не может быть. Общий анализ разработанных к настоящему времени теорий смешного позволил ему сделать вывод о том, что ни одна из них не может быть принята полностью. Вместе с тем он наметил в этом плане и весьма продуктивную исследовательскую установку. «Нетрудно, однако, заметить одно важное обстоятельство, - пишет он: - каждая из существующих теорий содержит некое рациональное зерно. Если рассматривать их не как законченные всеобъемлющие теории (на что обычно претендовали их создатели), а расценивать их как разработки отдельных положений, о тдельных сторон комического, то все встает на свои места и вместо хаотического нагромождения взаимоисключающих теорий возникает достаточно четкое и, на наш взгляд, непротиворечивое понимание сущности комического» [Санников 1999: 17].

Как представляется, к числу наиболее продуктивных аспектов такой интегрированной теории смешного должны быть отнесены следующие:

- $\quad$ смех - психологическая реакция на содержательные стимулы, уходящие корнями в глубины познавательной сферы человека;

- теория смешного должна быть ориентирована на глубинные познавательные уровни человеческой ментальности, на которых снимаются различия в знаковой природе представляемых содержаний;

- юмористические тексты с необходимостью двучленны в плане ситуативного содержания; смеховой эффект возникает при переходе от одной ситуации к другой, и чем неожиданнее этот переход, тем ярче смеховой эффект;

- наличие триггера для перехода от одной ситуации к другой в юмористических текстах необязательно; 
- представляемые в юмористических текстах ситуации могут вводиться последовательно, но могут и представляться одновременно на основе принципа игры;

- игра - важное условие юмора, составляющее предпосылку и форму существования юмора;

- в юморе принципиально важную роль играет принцип имплицитности: вторая ситуация часто оставляет для человека область догадки, постижение которой составляет основание смешного;

- смех связан с логической нормой и ее нарушением;

- смех связан с культурной (прагматической) нормой и ее нарушением или отклонением от нее.

Весьма показательно, что аспекты определяемой таким путем интегрированной теории вербального юмора отмечаются исследователями как факторы смешного в самых разных культурных условиях и по-разному расставляемыми акцентами. Так, условием иронического и в целом смехового осмысления действительности указывается игра как особый «инстинкт» и неотъемлемая часть человеческой культуры, по сути, выходящая далеко за ее пределы (играют и животные) [Баканурский, Сприсян 2004: 162; Кислов 2004].

С другой стороны, условием возникновения смешного указывается особая двойственность ситуаций или видений действительности, нетождественных друг другу. В этом плане весьма распространенной является метафора «кривое зеркало», посредством которой представляется идея постижения человеком в себе собственных недостатков. «В смеховой культуре, - пишет И. Одоховская, - сосуществуют, переплетаясь и взаимодействуя, два мира: реальный, отраженный смехом напрямую, и перевернутый, зеркальный, создающий особое пространство и свои закономерности, плод нашей фантазии и воображения» [Одоховская 2004: 156].

Также глубинным началом смешного указывается парадокс или прагматические несоответствия. При этом смех связывается с оценкой, которая, так же как игра, имеет универсальный характер. Ср.: «Смех в пространстве реального, не перевернутого мира является результатом оценки собственных или совершенных другими людьми поступков и действий, выявленного несоответствия между ожидаемым и ставшим, подразумеваемым и реализованным. Причины смеха - в житейских коллизиях и их противоречиях, в забавных совпадениях, наименованиях, диалогах, языковых перлах, в разнообразных эпизодах индивидуальной жизни и социума» [Одоховская 2004: 156].

$$
* * *
$$

1. Аристотель. Этика. Политика. Риторика. Поэтика. Категории. - Мн.: Литература, 1998. - 1392с.

2. Баканурский А., Сприсян В. Игра как способ иронического оформления жизни // « $\Delta \dot{\xi} \alpha$ / ДОКСА». Збірник наукових праць з філософії та філології. Логос і праксиссміху. 2004. Вип. 5. - Одеса: ОНУ ім. І. І. Мечникова. С. $162-173$.

3. Бахтин М.М. Собрание сочинений в семи томах. - Том 5. - М.: Русские словари, 1997. - 731с.

4. Евстафьева М.А. Когнитивные стратегии языковой игры (на материале русскоязычных и англоязычных анекдотов) - Диссертация... кандидата филологических наук. Калининград, 2006.

5. Карасев Л.В. Философия смеха. - М.: Рос. гуманит. ун-т, 1996. - 224c.

6. Кислов А. Смеховые «языковые игры»: подмена правил и эффект узнавания // «ธó $\alpha$ / ДОКСА». Збірник наукових праць з філософії та філології. Логос і праксиссміху. 2004. Вип. 5. - Одеса: ОНУ ім. I. І. Мечникова. С. $107-113$.

7. Одоховская И. Смех как самоотражение и дорога в зазеркалье // «ડ́́ $\alpha_{\alpha} /$ ДОКСА». Збірник наукових праць 3 філософії та філології. Логос і праксиссміху. 2004. Вип. $5 . \quad$ - Одеса: ОНУ ім. І. І. Мечникова. С. 153 - 161.

8. Пропп В.Я. Проблемы комизма и смеха. - СПб.: Алетейя, 1997. $-287 \mathrm{c}$.

9. Санников В.З. Русский язык в зеркале языковой игры. - М.: Языки русской культуры, 1999. - 544c.

10. Attardo, S. The Semantic Foundation of Cognitive Theories of Humor. - In: Humor: International Journal of Humor Research. - Berlin/New York: Mouton De Gruyter, 1997. - \#4. - P. 395-420. 
11. Attardo, S., Attardo, D.H., Baltes, P., Petray, M.J. The Linear Organization of Jokes: Analysis of Two Thousand Texts. - In: Humor: International Journal of Humor Research. - Berlin/New York: Mouton De Gruyter, 1994. - \#1. - P.27-54.

12. Attardo, S., Raskin, V. Script Theory Revis(it)ed: Joke Similarity and Joke Representation Model. - In: Humor: International Journal of Humor Research. - Berlin/New York: Mouton De Gruyter, 1991. - \#3/4. P. 293-347.

13. Forabosco, G. Cognitive Aspects of the Humor Process: The Concept of Incongruity. - In: Humor: International Journal of Humor Research. - Berlin/New York: Mouton De Gruyter, 1992. - \#1/2. - P.45-68.

14. Giora, R. On the Informativeness Requirement. - In: Journal of Pragmatics. Amsterdam: Elsevier, 1988. \#4/5. - P. 547-565.

15. Katz, B.F. A neural Resolution of the Incongruity-Resolution and Incongruity Theories of Humor - In: Connection Science, 1993. - \#5. - P. 59-75.

16. Nerhardt, G. Operationalization of Incongruity in Humour Research: A Critique and Suggestions. - In: It's a Funny Thing, Humour (Chapman A.J. and Foot H.C. (eds.). Oxford: Pergamon Press, 1977. - P. 47-51.

17. Raskin, V. Semantic Mechanisms of Humor. Dordrecht/Boston/Lancaster: D. Reidel Publishing Company, 1985. - $284 \mathrm{p}$.

18. Rothbart, M.K., Pien, D. A Theoretical Synthesis of Incongruity-Resolution and Arousal Theories of Humour - In: It's a Funny Thing, Humour (Chapman A.J. and Foot H.C. (eds.). Oxford: Pergamon Press, 1977. - P. 37-40.

19. Suls, J.M. Cognitive Processes in Humor Appreciation. - In: Handbook of Humor Research (McGee P.E. and Goldstein J.H. (eds.) - Vol.1. - New York/Berlin/Heidelberg/Tokyo: Springer-Verlag, 1983. - P.39-57.

\section{Пашкова Е.А. \\ Языковые и социокультурные особенности песенного дискурса (на материале русского и английского языков)}

Самарский государственный технический университет (Россия, Самара)

doi: $10.18411 / s p c-26-08-2018-03$

idsp: 000001:spc-26-08-2018-03

\section{Аннотация}

Настоящая статья посвящена исследованию языковым и социокультурным особенностям современного песенного дискурса в английском и русском языке. В ней рассматриваются, что такое песенный дискурс, тексты песен на английском и русском языках. Автор анализирует стилистические особенности такие повтор, риторический вопрос, метафора, имена собственные, эпитеты, отрицательные конструкции. Особое внимание уделяется эмоциональной экспрессивности рок -композиций, видение песни автором и ее влияние на реципиента. В заключении делается вывод о том какие сходства и различия есть в обоих языках, как влияют на слушателей, какой след могут песенные композиции оставить в определенный период времени или эпохи.

Ключевые слова: песенный дискурс, рок-композиции, языковые особенности, поэзия

Песенный текст прежде всего представляет собой креолизованный текст и он рассматриваться как единство мелодического и вербального компонентов, которые дополняют друг друга. Песенный текст сохраняет основные черты текстов поэтического дискурса: на уровне троп характеризуется наличием эпитетов, сравнений, метафор и интертекстуальных ссылок. Стилистически песенный текст можно рассмотреть как две основные тенденции: тяготение к повседневно-обиходному языку и противоположную - тяготение к стилю «серьёзной» поэзии. Особенно это можно проследить в текстах рок-композиций русский исполнителей. Песенный текст на данном этапе развития культуры фактически выполняет функции лирической поэзии, где мы видим всю подноготную лирического героя и поэтому ученым необходимы дальнейшие исследования лингвистического и лингвокультурологического планов. 
Русский рок начал активно осмысляться и пониматься в отечественной филологии как один из глобальных пластов современной русской поэзии. Если кратко охарактеризовать литературоведческие и лингвистические работы о русском роке, можно выделить три модели анализа, наследующие традициям отечественной филологии. Во-первых, это анализ в русле концепции широко понимаемого «самовитого слова» (термин В.П. Григорьева [1,с.15]), анализ, концентрирующийся на выявлении и понимании особенностей поэтики и стиля отдельных авторов, эстетическая значимость творчества которых является к настоящему моменту условно общепризнанной (Б. Гребенщиков, В. Цой, К. Кинчев, М. Науменко, А. Башлачев и мн. др.). Во-вторых, это успешные попытки обозначить и подчеркнуть направления и течения внутри рок-движения с опорой на осмысление его в контексте русской и, возможно частичной, зарубежной литературных традиций. В-третьих, это изучение русской рок-поэзии как единого обладающего эстетической актуальностью гипертекста, обнаруживающего некие лингвокогнитивные, стилистические, лексические, семантические, дискурсивные и другие присущие ему универсалии. Самобытное языковое существование личности в творчестве рассматривается в функциональном аспекте его способности порождать культуроформирующие и культуротрансформирующие коды, лежащие в основе динамики данной лингвокультуры, а не «в себе и для себя».

Рассматривая рок песни в отечественной культуре, мы погружаемся в ту эпоху и события, которые повлияли на написание песни, проводим определенные параллели, когда песня была написана, какие эмоции и переживания автор песни хочет до нас донести, что для него важно, как повлияла эпоха, в которой он жил и творил и как все это повлияло на реципиента. Песня в любую эпоху является отражением духа того времени, несет в себе идеологию того времени и является яростным протестом той эпохи и современных представителей музыкальных суб- и контркультур и выливается в протест против войны. Происходит связь поколений, и неважно, сколько прошло времени, столетие или двадцать лет. Авторы рок композиций больше других направлений и течений в музыке отражают свои протесты и недовольства, показывают дух бунтарства, и не боятся отвечать за свои слова, которые могут быть не по нраву правительству, другим поколениям и даже самой эпохе, в которой они существуют. Некоторым слушателям может быть не понятна их прямолинейность, неоднозначность высказываний, которые обычно режут слух, непринятие правды.

Особый интерес представляет личность лидера группы «Кино» Виктора Цоя. Он стал символом героической эпохи русского рока, объектом мифологизации и сакрализации. Он является образом прецедентности своей эпохи и нынешнего поколения. Молодежь во все времена копировала образ и верила в то, что В. Цой жив, даже сейчас десятилетия спустя, мы видим неугасающий интерес людей к произведениям В. Цоя. Многим людям в нашей стране близки по духу песни В. Цоя.

В тексте песни В. Цоя «Хочу перемен» мы видим эпоху перестройки в 1986-87 гг.; в стране наступает эпоха гласности, происходит смена власти, разные поколения хотят перемен, и особенно это касается молодежи. При помощи повторов мы видим всю экспрессию, силу бушующих эмоций в этих словах, страсть к чему-то новому и неизведанному, надежду на новое будущее, какое хотела получить молодежь в то время. Видна вся страсть и эмоциональная ответственность автора, за текст песни, что он сам хочет того же:

"Перемен!" - требуют наши сердияа.

"Перемен!" - требуют наши глаза.

В нашем смехе и в наших слезах,

И в пульсации вен:

"Перемен! Мы ждем перемен!" (В. Цой «Перемен»)[2] 
В 90-е г. многие авторы песен рок-композиций посвящали теме войны. На войне гибнет молодежь, иногда войну начинают главы государств, а не сами люди, у них нет желания убивать друг друга:

И две тысячи лет война -

Война без особых причин

Война - дело молодых

Лекарство против морщиин (В. Цой «Звезда по имени Солниее))[3]

Проанализировав текст песни, можно сделать вывод, что автор песни хочет донести до нас свое эмоциональное состояние, его переживания, связанные с теми событиями, которые были в его жизни, показать проблемы той эпохи и тех людей, которые жили тогда. Когда создавалась эта песня, страна воевала, и многие молодые гибли, хотели перемен, найти смысл жизни. При помощи стилистического приема как повтор, можно увидеть эмоциональную и глубинную привязанность, о том, что автор рок-композиции хочет донести до реципиента., доказать. Что он тоже рядом со слушателем.

Проведенный анализ предметно-референтных ситуаций текстов русских роккомпозиций показывает, какие темы ближе нашим соотечественникам, а именно: война, страдание, любовь, невозможность исправить и вернуть все назад. Тексты песен насыщенны эмоциональностью, экспрессивностью, связаны с переживаниями о мире, о проблемах, которые существуют, о чувствах неразделенной любви, наполнены различными символами, которые могут пониматься людьми по-разному, но в тоже время близки духовно.

Рассмотрим языковые и социокультурные особенности англоязычного песенного дискурса, специфика которого обусловлена историей и культурой англоязычных стран.

Анализируя текст песни «Alexander the Great» группы Iron Maiden можно увидеть достаточно большое количество имен собственных, которые помогают нам лучше понять автора и то, что он хочет сказать текстом песни. В тексте песни использованы следующие имена собственные: Macedonia, Greece, Asia, Persia, Egypt, Babylon, India; благодаря этим средствам мы видим, что Александр Великий завоевал большое количество стран, был великим царем, который сумел завоевать полмира, у него было много битв с великими царями того времени.

Также здесь можно увидеть употребление архаичной и диалектичной формы местоимения уоu, которая говорит нам об ушедшей эпохи царствования:

My son ask for thyself another

Kingdom, for that which I leave

is too small for thee. (Iron Maiden "Alexander the Great")[4]

Содержание текста песни свидетельствует о человеке, сделавшего себя самого, прославившего свое имя навечно:

The legend his name was Alexander. (Iron Maiden "Alexander the Great")

В тексте композиции использована метафора, которая выражает страх и ужас: даже великие люди той эпохи приходили в ужас при упоминании имени А. Македонского. Метафора ярко показывает действия имени Македонского на его врагов:

King Darius the third, Defeated fled Persia,

The Scythians fell by the river Jaxartes. (Iron выражает отношение автора песни к известного личности:

He became the Macedon king

Alexander the Great,

His name struck fear into hearts of men. (Iron Maiden "Alexander the Great")

Дальше мы можем увидеть историю его похода в Азию, где он храбро сражался, как принес западную культуру и стиль жизни, став хозяином Азии. Благодаря своим 
завоеваниям он не уничтожил другие цивилизации, а дал им возможность самим развиваться:

He would become the master of Asia. (Iron Maiden "Alexander the Great")

Автор песни показывает слушателю, что Александр пытался принести другим народам христианство, но не грубой силой, а только учитывая желание самого народа:

He paved the way for Christianity. (Iron Maiden "Alexander the Great")

Его великий поход продолжался. И вместе со своими воинами в зените славы он добрался до Индии. Благодаря эпитетам, которые его восхваляют, показывают величие, ум, неординарность и умение быть великим полководцем, мы понимаем, что он был необычным человеком и по настоящему великим:

Alexander's army line by line,

They wouldn't follow him to India,

Tired of the combat, pain and the glory. (Iron Maiden "Alexander the Great")

Полученные в результате проведенного исследования и анализа текстов английских и русских рок-композиций показанные результаты свидетельствуют о сложности и многогранности данной проблемы в изучении текстов песен, схожи они во многих чертах. Например, тема смерти актуальна для русского и английского рока, философские переживания тоже отражаются в композициях. Отличие в том, что в русских рок-композициях не упоминается о каких либо великих людях, для них это не важно, самое главное это любовь. Исследования текстов песен очень перспективны и интересны, поскольку они дают представление об особенностях жизни современного как англоязычного социума так и русскоязычного, которые находят отражение в текстах песен, представляющих собой одно из проявлений современной массовой культуры.

$$
* * *
$$

1. Григорьев В.П. Поэтика слова. - М., 1979. - С. 76.

2. В.Цой «Перемен» http://lyricshare.net/ru/kino-viktor-coy/peremen.html

3. В.Цой «Звезда по имени солнце» http://lyricshare.net/ru/kino-viktor-coy/zvezda-po-imeni-solnce.html

4. Iron Maiden «Alexander the Great»http://www.megalyrics.ru/lyric/iron-maiden/alexander-the-great.htm

\section{Родионова И.П. \\ Проблема определения терминов «языковой контакт» и «смешение языков»}

Байкальский государственный университет (Россия, Иркутск)

doi: $10.18411 / s p c-26-08-2018-04$

idsp: 000001:spc-26-08-2018-04

Как известно, проблеме языковых контактов лингвисты всегда уделяли особое внимание. Причины, условия и результаты взаимовлияния языков исследовались не только в прошлом. Вопрос о языковых изменениях остается актуальным в современной лингвистике. В связи с многообразием языков, всегда будет существовать проблема их взаимодействия и невозможно представить будущее народов всего мира без общения на более новом и доступном уровне. До сих пор не найдены ответы на необходимые поставленные вопросы, связанные с процессом контактирования языков, в связи с тем, что данный процесс является исторически сложным и многоплановым. Вот почему нельзя не согласиться с уместным замечанием выдающегося русского лингвиста, Л.В.Щербы, о том, что «понятие смешения языков - одно из самых неясных в современной лингвистике, так что, возможно, его и не следует включать в число лингвистических понятий, как это и сделал А. Мейе» [6]. Сам термин «смешение» подвергался неоднократно нападкам со стороны различных языковых школ, но современные отечественные и зарубежные лингвисты продолжают употреблять этот термин. 
А. Мартине, высказывая своё мнение о причинах распространения языка, утверждал, что «любой язык является побочным продуктом военной, политической, религиозной, культурной, экономической или просто демографической экспансии народа, чьим орудием общения является данный язык. Таким образом, ничто не предрасполагало к распространению латинского, арабского, испанского и английского языков далеко за свои первоначальные пределы» [2].

Автор теории «географического варьирования», австрийский лингвист Гуго Шухардт, ученик Августа Шлейхера, считал потенциал языкового смешения абсолютно безграничным и это может привести к максимальному, либо минимальному различию между языками. Смешение языков может иметь место при постоянном пребывании на одной и той же территории, именно в этом случае оно проявляется интенсивно и осуществляется сложным путем. Отрицая понятие единства системы языка, ученый переходит от национального языка к «индивидуальному языку», расширяя понятие «языкового смешения» и отождествляя с ним общение людей, осуществляемое посредством языка. Каждый отдельный человек видоизменяет свой язык в общении с другими людьми. Проблему языкового смешения Г. Шухардт считал самой важной среди тех проблем, которыми занималось в то время языкознание. Ни один язык не может существовать отдельно от скрещений и внедрения чужих элементов [8]. Вот почему понятие «смешения языков» неразрывно связано с такими явлениями как языковые контакты, билингвизм, диалектология и лингвистическая география. В свою очередь, изучение языковых контактов раскрывают сущность таких явлений как билингвизм и двуязычие.

Как следует заметить, причины данного процесса имеют социальный и психологический характер. Исследование языкового контакта можно лучше всего понять только в широком психологическом и социокультурном контексте. Влияние языков друг на друга неоспоримо и использование только данных лингвистического описания недостаточно. Лингвистическое изучение языкового контакта необходимо соотносить с экстралингвистическим изучением двуязычия и связанных с ним явлений. Невозможно глубже и существеннее понять проблему языковых контактов без знаний основанных на междисциплинарной основе. Например, двуязычное население могут описывать географы и этнографы, социологи занимаются исследованием функционирования языков, психологи занимаются анализом проблемы влияния двуязычия на личность и в этом им помогают педагоги, обучая неродному языку билингвов, антропологи рассматривают языковой контакт как один из аспектов контакта культур.

Как мы видим термины «языковой контакт» и «смешение языков» употребляются широко зарубежными и отечественными лингвистами и на первый взгляд имеют одинаковое значение. Что касается термина «смешение языков», то здесь единого мнения не существует. Как мы помним, данный термин появился ещё до того, как была написана работа У.Вайнрайха «Языковые контакты». Одни лингвисты относятся к данному термину скептически, считая его ненужным и бессмысленным, другие его просто заменили на термин «языковай контакт» как это сделали А. Мартине и впоследствии У. Вайнрайх.

Г. Шухардт считал, что «вопрос о смешении языков, который самым тесным образом связан с вопросом двуязычия довольно сложен и может быть выяснен при помощи психологии» [9].

Л.В. Щерба предлагал вместо термина «смешение языков» употреблять термин «взаимное влияние языков», считая, что слово «смешение» предполагает, что оба языка, находясь в непосредственном контакте, могут в равной степени участвовать в образовании нового языка, особенно, если это касается языков, история которых нам неизвестна, «анализируя такой язык, можно констатировать, что его элементы восходят к другим языкам» [5]. 
Из-за некоторых фактов (заимствования в собственном смысле слова, сделанные данным языком из иностранных языков; изменения в том или ином языке, которыми он обязан влиянию иностранного языка; факты, являющиеся результатом недостаточного усвоения языка;) Л.В. Щерба не видел пользы в том, чтобы два языка находящихся в контакте объединить в одну общую рубрику под названием «смешение языков».

Факты второй категории идентичны фактам третьей, так как часто основываются на процессах, подобных тем, которые имеют место внутри одного и того же языка [7].

То же самое касается языковых контактов и взаимодействия языков. По мнению Ю.А. Жлуктенко, отличие в соотношении состоит в том, что первое явление существует как причина, а второе как следствие. «Пока между двумя языками не установится тот или иной тип контакта, между ними не может быть никакого взаимодействия. Между двумя парами языков может установиться одинакового типа контакт, а взаимодействие между ними может приобретать разный характер, в зависимости от целого ряда лингвистических и внелингвистических факторов». Другими словами, можно сказать, что такое явление как языковые контакты это нечто иное как «интерлингвистические связи, которые устанавливаются при взаимодействии двух или более языков» [1].

С.В. Семчинский даёт определение термину «языковой контакт», под которым понимает «явление, охватывающее разнообразные языковые связи, проявляющиеся на всех лингвистических уровнях и устанавливающиеся при наличии определенных историко-географических, общественно-политических, культурных, психологических и других факторов между языками, независимо от их генеалогического родства или типологической близости» [4].

Мы видим насколько разнообразно и неоднозначно интерпретируется явление ЯК (языковые контакты). Ученые, которые занимаются этой проблемой, каждый имеет своё особое видение ЯК. Одни считают, что правомерно отождествлять понятие языкового контактирования с понятием взаимодействия языков (С.В.Семчинский, В.Н.Ярцева), другие - наоборот полагают, что это может привести к серьёзным ошибкам (Ю.А.Жлуктенко, Т.П.Ильяшенко) .

В современной лингводидактике является бесспорным тот факт, что обучение второму языку должно осуществляться через родную культуру и родной язык, вот почему исследование языковых контактов - одна из важнейших задач современного языкознания [3]. Мы с большой долей вероятности можем утверждать, что сам фактор языкового контактирования является особенно значимым в трансформации языков во времени и пространстве, независимо от того, как мы интерпретируем такие понятия как «языковой контакт» и «смешение языков».

$$
* * *
$$

1. Жлуктенко Ю.А. Лингвистические аспекты двуязычия. К.,1970.с.12

2. Мартине А. Распространение языка и структурная лингвистика. Новое в лингвистике. - Вып. 6. - М., 1972. - C. $81-93$

3. Пугацевич. И.П., Рогозная Н.Н. Интерязык как промежуточная система в условиях билингвизма "Вестник ИрГТУ” № 4,435с.-439с., Иркутск: Изд-во ИрГТУ, 2015.-453с

4. Семчинский С.В. Семантична інтерференція мов. п̃ К.: Вища школа, 1974. ñ 256c. С.13

5. Щерба Л. В. Избранные работы по языкознанию и фонетике. Т. 1. - 1958., с.42

6. Щерба Л.В Указ соч., с.60

7. Щерба Л.В. Языковая система и речевая деятельность. - Изд. 2-е, стереотипное. М.: Едиториал УРСC, 2004. C.60-C.61- $432 \mathrm{c}$

8. Шухардт Г. К вопросу о языковом смешении / Г. Шухардт // Шухардт Г. Избранные статьи по языкознанию / пер. с нем. А. С. Бобовича. - М. : Изд-во иностранной литературы, 1950 - С. 174-184.

9. Hugo Schuchard «Zur Afrikanischen Sprachmischung». Das Ausland., 1882., S.868 


\section{РАЗДЕЛ ІІ. КУЛЬТУРОЛОГИЯ}

\section{Касьяненко В.В. \\ Политические идеи Ивана Грозного и А. Курбского и их изучение в отечественной исторической науки}

Кубанский государственный университет

(Россия, Краснодар)

doi: $10.18411 / s p c-26-08-2018-05$

idsp: 000001:spc-26-08-2018-05

Заметное влияние на политическое развитие Московского государства XVI в. оказала дискуссия о путях развития страны, возникшая между А.М. Курбский и Иваном Грозный. Именно теории этих авторов оказали решающее влияние не только на современную литературу, но и на последующие развитие публицистики в России и в конечном итоге на ее политическую эволюцию.

Методологической основой данной статьи является тезис о том, что политические взгляды публицистов основаны на мифологизации процесса. Так как теории мыслителей опирались на эсхатологические мифы, они не могли быть осуществлены и таким образом превращались в утопию (несбыточную мечту). Впоследствии эти утопии могли стать (и становились) основой для новых мифов, которые вновь превращались в утопию.

Переписку между Курбским и Иваном Грозным, историки XIX в. обычно трактовали с политической точки зрения. Начало такому подходу положил Н.М. Карамзин. По его мнению, «первым делом Курбского было изъясняться с Иоанном, открыть душу свою, исполненную горести и негодования. В порыве сильных чувств он написал письмо царю... Царь, волнуемый гневом и внутренним беспокойством совести, немедленно отвечал Курбскому».

Иначе, чем Н.М. Карамзин, С.М. Соловьев объясняет смысл переписки Грозного и Курбского. "В ней высказались не одни только, личные современные отношения, в ней вскрылась историческая связь явлений. Иоанн в ответ потомку ярославских князей высказывает цель своего правления и превосходства, нового порядка вещей". Переписка, по мнению автора, это спор сторонников "старого" и "нового порядка вещей". За Курбским стояли старые "родовые начала", за Грозным - новые "государственные".

Не ясно, за какие именно родовые начала мог выступать в XVI в. А. Курбский, не был он противником «государственных начал и сторонником раздробленности страны». Также не понятно, чем, по мнению С.М. Соловьева отличался, «старый порядок от нового».

На эти недочеты указывали уже современники С.М. Соловьева, поэтому после него высказывались сомнения в том, имел ли вообще этот спор идеологический смысл. В исторических трудах началось отрицание значения переписки. В частности Н.И. Костомаров выразил даже недоумение, зачем царь писал Курбскому.

В.О. Ключевский продолжил тенденцию в исследовании переписки Грозного и Курбского. Он, как и предыдущие историки отрицал ее значение. В.О. Ключевский даже подчеркнул ее бессмысленность, показав на основе почти точных цитат взятых из переписки, что боярин и царь, не понимают и не хотят понимать друг друга: «Каждый из них твердит свое и плохо слушает противника: 
- За что ты бьешь нас, верных слуг своих? - спрашивает князь Курбский.

- Нет - отвечает ему царь Иван - русские самодержцы изначала сами владеют своими царствами, а не бояре и не вельможи».

С.Ф. Платонов первым попытался определить смысл спора между Грозным и Курбским. Он полагал, что опричнина (учрежденная в 1564 г., вскоре после начала переписки) была реформой, направленной против бояр-князей, которых Грозный лишал земельных владений. По мнению С.Ф. Платонова, в переписке «обе стороны монарх, стремившийся «сам править» и князь-боярин, представляющий принципы боярской олигархии, обменялись мыслями с редкою откровенностью и резкостью... В полемике Грозного и Курбского вскрывался истинный смысл избранной знати, которая, очевидно, служила орудием не бюрократическим - боярской, а удельно-княжеской политики». Таким образом, переписка была как бы своеобразной программой Грозного.

Послания Грозного, по мнению Покровского, выражали «новую мысль». «Нет ничего несправедливее, как отрицать принципиальность царя в его борьбе с боярами и видеть в этой борьбе какое-то политическое топтание на одном месте», - писал Покровский. Новыми у него была экономическая характеристика самодержавия Грозного как государственного строя опиравшегося на «торговый капитал» и противостоящего старому феодальному.

В ранней советской историографии, до 40-х г. XX в., предпринимались попытки проверки того объяснения событий 1564 г. и переписки Курбского и Грозного, которое изложил Платонов. Хотя его взгляды встречали поддержку среди историков (Садиков, Бибиков и др.), в тоже время были и некоторые возражения, в частности, у С.Б. Веселовского. С начала 40-х г. ХХ в. при поддержке политического руководства страны, начинается своеобразный переворот в оценке Грозного. Показательна статья В.И. Костылева «Литературные заметки», опубликованные в марте 1941 г. Автор предлагал отвергнуть все источники о Грозном, которые писали его недоброжелатели и пересмотреть оценку в истории Ивана IV, который сумел создать государство, устоявшее в годы Смуты. К этой теме обратились другие деятели искусства, создавшие многочисленные произведения о «великом государе»; этой же концепции следовали историки. Так С.Б. Бахрушин характеризовал в 1942-1945 гг. Ивана Грозного, как «крупного государственного деятеля своей эпохи, верно понимавшего интересы и нужды своего народа боровшегося за их удовлетворение», а Курбского как «апологета боярства», бывшего удельного князя, изменившего своей стране и противника своего народа. Мысль о Грозном как борце за счастье соотечественников представляла собой новое явление в историографии марксистского периода. Общую оценку апологетической литературы о Грозном дал С.Б. Веселовский, крупный исследователь эпохи Ивана Грозного, в статье написанной им еще в 1944-1945 гг., но увидевшей свет лишь в 1963 г. Поводом для статьи послужила рецензия Н.С Державина на книгу В. Костылева, в которой он писал, что события царствования Ивана IV лишь сравнительно недавно получили в историографии правильное толкование. Возражая ему С.Б. Веселовский писал, «что Грозного восхваляли и ранее, но для подлинных открытий в науке, необходим большой и добросовестный труд над источниками, новый фактический материал».

С конца 50-х г. ХX в. интерес к переписке Грозного и Курбского возрос. Посмертно издан сборник работ С.Б. Веселовского. Опубликованы исследования по опричнине (А.А. Зимина, Р.Г. Скрынникова, В.Б. Кобрина). Однако, апология Грозного в работах предшественников вызвала своеобразную историографическую реакцию. 
Ярче всего это отразилось в работе С.М. Дубровского (1956 г), который характеризовал власть Грозного как тиранию и полностью отверг его роль как писателя и публициста, заявив, что при отсутствии прижизненных автографов авторство царя сомнительно.

Появились сомнения и в публицистическом значении переписки. Схема С.Ф. Платонова вызвала серьезные возражения в советской историографии. С.В. Бахрушин отметил дворянский характер многих из реформ «Избранной рады» и это получило дальнейшее развитие в работах А.А. Зимина и И.И. Смирнова .

Серьезному пересмотру подвергся взгляд С.Ф. Платонова на опричнину как реформы, целью которой была уничтожение вотчинного земледелия бояр. С.Б. Веселовский показал, что на землях, взятых в опричнину, почти не было княжеских вотчин, этот вывод был подтвержден А.А. Зиминым. Все это давало последователям повод выразить сомнения в антибоярской земельной политики и годы опричнины.

С.Б. Веселовский ставил вопрос еще резче. Он предлагал возвращение к точке зрения Ключевского, согласно которой внутренняя политика Ивана IV определялась его психологическим состоянием и сводилась к истреблению лично неугодных царю лиц. Согласно этому переписка Грозного и Курбского чисто психологически в духе Карамзина.

Интерес к переписке Грозного и Курбского резко возрос после 1971 г. и опубликования книги Э. Кинана. Американский исследователь пришел к выводу, что первое письмо Курбского, как и вся его переписка с Грозным, является литературной мистификацией XVI в.. Основанием для этого послужило обнаруженное Э. Кинаном текстуальное сходство в послании Курбского и в «Жалобе» литовского монаха Исайи. Будучи в заключении в Вологде, Исайя написал свое письмо в 1566 г., а Курбский - в 1564 г. Считая письмо монаха первичным, Кинан заключил, что письмо Курбского подложно, как и вся переписка.

Вывод, сделанный Кинаном, положил начало дискуссии, в которой приняли участие не только ученые-медиевисты России, но исследователи из других стран. Аргументы Э. Кинана были подробно проанализированы в 1973 г. Р.Г. Скрынниковым. По его мнению, Исайя написал свое письмо вскоре после июля 1562 г. Тайную переписку с ним вели те самые русские эмигранты, которые вскоре завязали отношения с Курбским. От них беглый боярин и получил сочинение Исайи, из которого и сделал выписку в 1564 г.. Андреев и Я.С. Лурье полагают, что именно послание Курбского послужило источником для «Жалобы» Исайи. Монах его мог получить в ходе тайных сношениях, во время заключения, со своими доброжелателями.

Я.С. Лурье полагает, что переписка Грозного и Курбского принадлежит к жанру агитационной литературы и именно в этом заключается ее идеологический смысл. Свой вывод он делает на основе того, что современники были знакомы с перепиской (приводит в качестве примера случай с монахом Исайя). И также Лурье строит доказательство на базе того, что в заголовке царского послания написано, что монарх адресовал свое письмо во все Российское государство, из чего сделает вывод, что Иван IV и Курбский обменивались открытыми, адресованными широкому кругу читателей, письмами.

В историографии второй половины 80-90-х гг. начинается новый этап в изучении переписки Курбского и Грозного. На первое место выходит изучение личности в историческом процессе. Акцент делается на психологический аспект. Поэтому переписка рассматривается через призму личного столкновения. Р.Г. Скрынников отрицает объяснения посланий Грозного, предложенные Я.С. Лурье. 
Автор указывает на то, что переписка не могла принадлежать к жанру открытых писем, так как это никак не отразилось в рукописной традиции XVI в.. Р.Г. Скрынников дает свою трактовку причин возникновения переписки: «На протяжении длительного времени царя Ивана и князя Курбского связывала личная дружба. Разрыв вызвал жгучую потребность объясниться начистоту, выразить накопившиеся обиды». Это объяснение сближает позиции автора с позициями историков первой половины XIX в. и крайне похоже на формулировку данную Н.М. Карамзиным в своей «Истории государства Российского».

Таким образом, анализ историографии данной тематики с одной стороны, показывает политизированный характер изучаемой проблемы, с другой насущную потребность комплексного рассмотрения.

$$
\text { *** }
$$

1. Хоффманн И. Национальные мифы, региональные традиции-препятствия на пути к единой Европе //Известия вузов. Общественные науки. 2001. № 1.

2. Костомаров Н.И. Исторические монографии и исследования. Т. 12.

3. Платонов С.Ф. Полный курс лекций по русской истории. Ростов-на-Дону, 1997.

4. См.: Веселовский С.Б. Синодик опальных как исторический источниковедения. Т. 3. М., 1990.

5. Бахрушин С.В. Научные труды. Т. 2. М.;Л., 1954.

6. Веселовский С.Б. Исследования по истории опричнины. М., 1963.

7. Зимин А.А. Опричнина Ивана Грозного. М., 1963.

8. Скрынников Р.Г. Переписка Грозного и Курбского. Парадоксы Эдварда Кинана. Л., 1973.

9. Лурье Я.С. Переписка Ивана Грозного с Курбским в общественной мысли Древней Руси. Л., 1979.

10. Скрынников Р.Г. История Российская IX - XVII вв. М., 1997. 


\section{SGIENGEPUBLIC}

Научное издание

Научный диалог:

Филология, Культурология, Искусствоведение

Сборник научных трудов, по материалам

XIII международной научно-практической конференции

26 августа 2018 г.

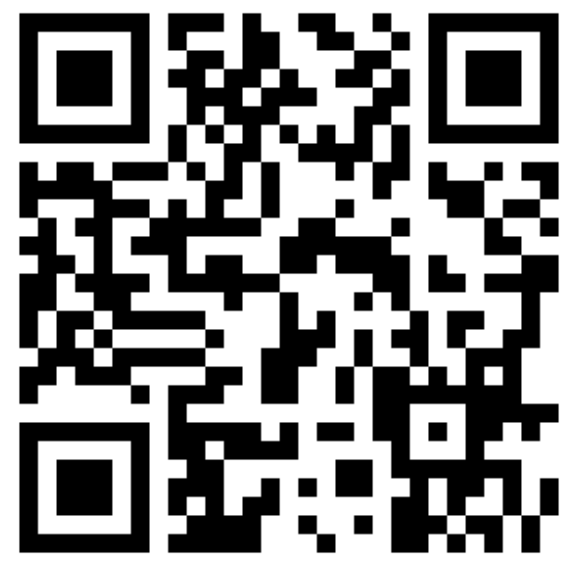

SPLN 001-000001-0327-FI

Подписано в печать 10.09.2018. Тираж 400 экз.

Формат.60х841/16. Объем уч.-изд. л.1,6

Бумага офсетная. Печать оперативная.

Отпечатано в типографии НИЦ «Л-Журнал»

Главный редактор: Иванов Владислав Вячеславович 